\title{
Post road traffic accident one-month old, extra-large heel defect coverage by delayed reverse sural artery flap: an interesting case report
}

\author{
Madhusoodan Gupta $^{1 *}$, Deepti Varshney ${ }^{2}$, Vishal K. Biswkarma ${ }^{3}$
}

\author{
${ }^{1}$ Department of Plastic Surgery, Sri Sai Super speciality Hospital, Moradabad, Uttar Pradesh, India \\ ${ }^{2}$ Department of Pathology, Pathkind labs Moradabad, Uttar Pradesh, India \\ ${ }^{3}$ Department of Pharmacology, Kharvel Subharti College of Pharmacy, SVSU, Meerut, Uttar Pradesh, India
}

Received: 29 May 2021

Revised: 02 July 2021

Accepted: 03 July 2021

\author{
*Correspondence: \\ Dr. Madhusoodan Gupta, \\ E-mail: drmsgupta12@gmail.com
}

Copyright: ( ) the author(s), publisher and licensee Medip Academy. This is an open-access article distributed under the terms of the Creative Commons Attribution Non-Commercial License, which permits unrestricted non-commercial use, distribution, and reproduction in any medium, provided the original work is properly cited.

\begin{abstract}
Post road traffic accident (RTA) complete heel avulsion injury is not very common, but once it happened, it is very challenging to plastic and reconstructive surgeon to reconstruct the total heal avulsion defect. There is paucity of soft tissue in the region of foot, ankle and lower one third of leg. Although the micro vascular free flap reconstruction is gold standard for reconstruction of large heel defect but not feasible most of the time. Reverse sural artery flap (RSAF) is a workhorse flap for reconstruction of heel and lower $1 / 3^{\text {rd }}$ leg defect. Here we reported a case of 28 years old young man, who had road traffic accident and sustained complete right heel avulsion injury with calcaneal and right tibia bone fracture. Patient was presented to author one month later after the injury with extra-large infective right heel defect size $15 \times 12 \mathrm{~cm}$ with k-wires in exposed calcaneal bone. Patient's surgery was done in two stages. Delayed RSAF survived completely and well settled in our case.
\end{abstract}

Keywords: Reverse sural artery flap, Heel avulsion defect, Microvasular free flap, Delayed RSAF

\section{INTRODUCTION}

Post road traffic accident (RTA) complete heel avulsion injury is not very common, but once it happened, it is very challenging to plastic and reconstructive surgeon to reconstruct the total heal avulsion defect. ${ }^{1}$ There is paucity of skin and soft tissue in the region of foot, ankle and lower one third of leg. This makes the scenario more difficult to reconstruct the heel defect. There are various methods to reconstruct the foot defect by loco regional flaps, muscle flap, myocutaneous flaps, fasciocutaneous flaps and microvascular free tissue transfer. ${ }^{2}$ Each and every procedure has their advantages and limitations. Although free flap surgery is the gold standard for reconstruction of extra-large heel defect but not feasible in majority of patients due to some problems such as learning curve, expertise, long hours of surgery, long hospital stay and cost. ${ }^{3}$ Reverse sural artery (RSAF) is a workhorse flap for reconstruction of heel and lower $1 / 3^{\text {rd }}$ leg defect. ${ }^{4,5}$

RSAF was initially introduced by Donski and Fogdestam and later on presented by Masquelet et al. RSAF has become a popular option for difficult wounds.${ }^{6,7}$ Here author reports a case of 28 years old young man who had road traffic accident and sustained total right heel avulsion injury with calcaneal and right tibia bone fracture. Bony fractures were managed by orthopaedic surgeon outside. Patient was presented to author one month later after the injury with extra-large infective right heel defect size $15 \times 12 \mathrm{~cm}$ with $\mathrm{k}$-wires in exposed calcaneal bone. Surgery was done in two stages. In first stage radical debridement and VAC (Vacuum assisted closure) dressing of heel defect along with strategic delay of RSAF was done. Delayed procedure increases the 
survivability of RSAF in large defects. ${ }^{89}$ In second stage again debridement, elevation of flap, transposition and flap in setting with donor site split thickness skin grafting was done. Delayed RSAF survived completely and well settled in our case.

\section{CASE REPORT}

28 years old male young patient who had road traffic accident and sustained fracture of shaft of right tibia and calcaneal bone along with complete avulsion of right heel pad. Bony fractures were managed outside by plating for tibia fracture and k-wires fixation for calcaneal bone fracture. Patient was presented to author after one month. On local examination there was a single extra-large wound located over the right hind foot, size $15 \times 12 \mathrm{~cm}$. It showed multiple necrotic areas and unhealthy granulation tissue along with dry, discoloured calcaneal bone and exposed tendo achilies with k-wire in situ (Figure 1). Wound swab for pus culture sensitivity was taken. Surgery was planned in two stages. In first stage- patient was positioned supine under spinal anaesthesia. Standard marking for RSAF and peroneal perforator identification was done with hand held doppler. Two perforators were identified one at $5 \mathrm{~cm}$ and another at $7 \mathrm{~cm}$ proximal from the lateral malleolus. Both perforators were kept in pedicle of RSAF. Extensive debridement of wound including all necrotic soft tissue as well as calcaneal bony cortex was debrided (Figure 2). Defect measurement and template was made. RSAF planning in reverse was done. VAC dressing done over the right heal wound. Strategic reverse sural artery flap delay was done (Figure 3). After 4 days VAC dressing was changed. Second surgery was done on day 11. RSAF elevation (Figure 4), transposition and flap in setting along with donor site split thickness skin grafting was done. RSA flap survived completely without any margin necrosis (Figure 5). Donor site skin graft well settled. 7 months post op result was shown in picture (Figure 6). Patient is able to walk normally with normal range of motion of right ankle joint.

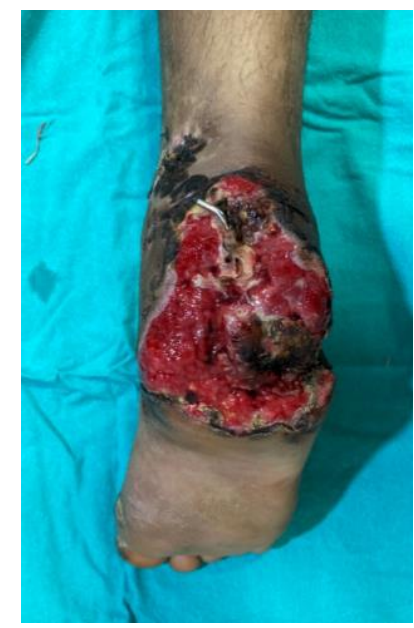

Figure 1: A large wound located over the right hind foot, dry, discoloured calcaneum bone and exposed tendo achilies with k-wire in situ.

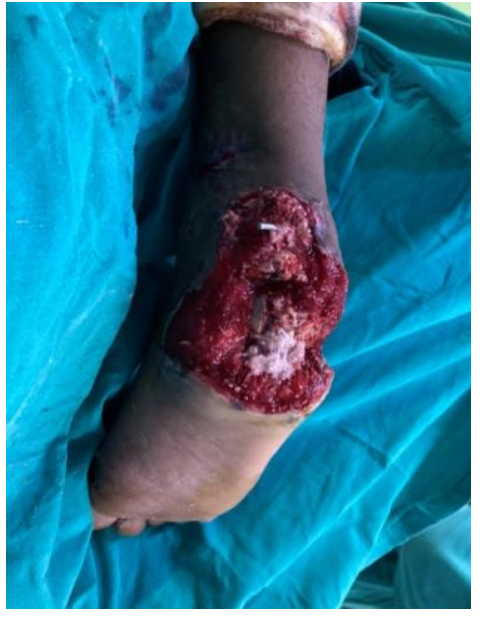

Figure 2: Extensive debridement of wound including all necrotic soft tissue as well as calcaneal bony cortex was debrided.

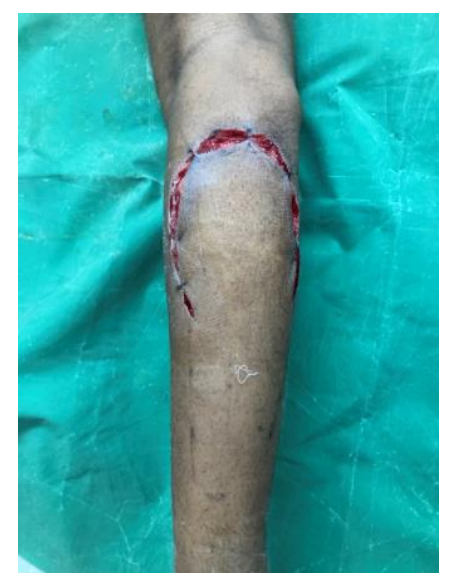

Figure 3: Strategic reverse sural artery flap delay.

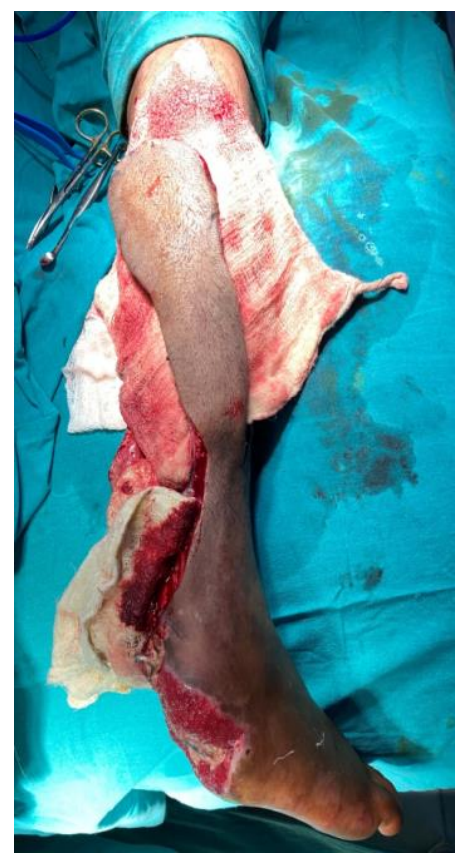

Figure 4: Reverse sural artery flap elevation. 


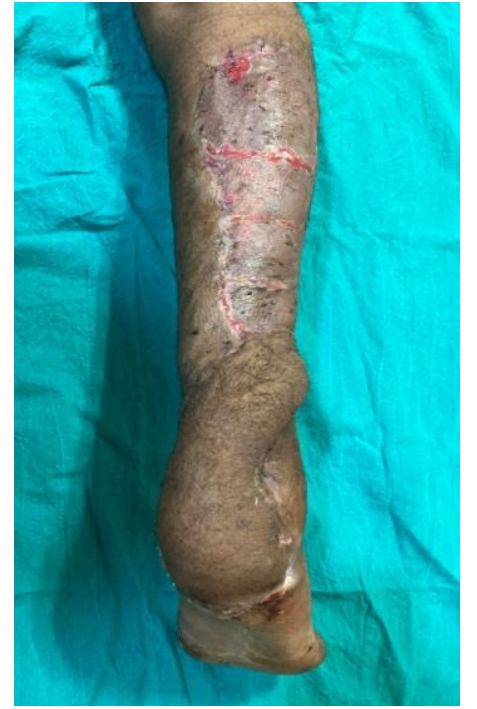

Figure 5: RSAF survived completely without any margin necrosis.

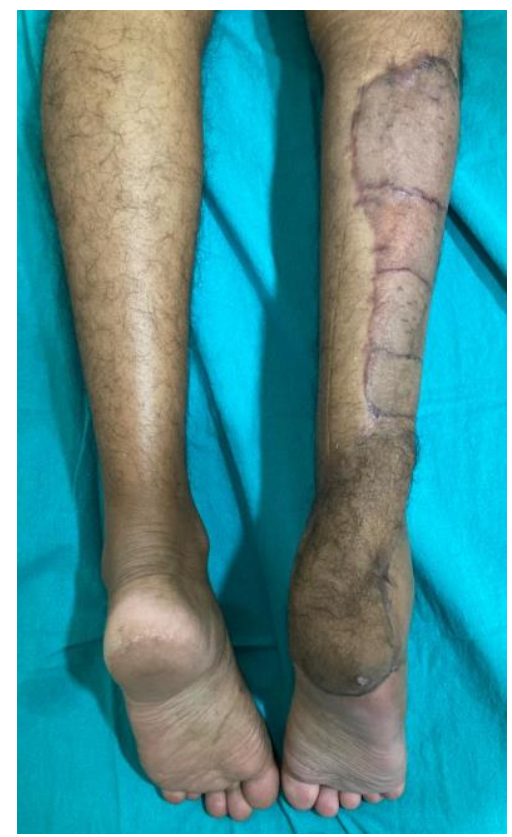

Figure 6: 7 months post-op result.

\section{DISCUSSION}

Large heal defect is challenging to reconstruct. Pedicle RSAF is workhorse flap for heel defect, but literature showing partial and complete necrosis of RSAF specially in large size defect. To overcome this dreaded complication of RSAF, we planned the strategic delay of RSAF. After delaying chances of flap survivability increases.

Many authors also claimed that after delaying, the flap related complications can be decreased. ${ }^{10-12}$ In this case complete survival of RSAF was seen. Although sural nerve sensory loss is a known complication of reverse sural artery flap.

\section{Limitations}

This was two stage procedure and it required good vascularity of reverse sural artery angiosomes territory. Otherwise partial or complete necrosis of reverse sural artery may occur.

\section{CONCLUSION}

Although numerous other options are available for large heel defect. Delayed reverse sural artery flap is preferred due to its easy dissection, constant anatomy, durable skin cover, sensate soft tissue covering for heel and almost negligible donor site morbidity making this flap as a workhorse for large heel defect.

\section{Funding: No funding sources Conflict of interest: None declared Ethical approval: Not required}

\section{REFERENCES}

1. Yan H, Liu S, Gao W, Li Z, Chen X, Wang C, et al. Management of degloving injuries of the foot with a defatted full-thickness skin graft. J Bone Joint Surg Am. 2013;95(18):1675-81.

2. Ong YS, Levin LS. Lower limb salvage in trauma. Plast Reconstr Surg. 2010;125(2):582-8.

3. Heller L, Levin LS. Lower extremity microsurgical reconstruction. Plast Reconstr Surg. 2001;108(4):1029-41.

4. Akhtar S, Hameed A. Versatility of the sural fasciocutaneous flap in the coverage of lower third leg and hind foot defects. J Plast Reconstr Aesthet Surg. 2006;59(8):839-45.

5. Follmar KE, Baccarani A, Baumeister SP, Levin LS, Erdmann D. The distally based sural flap. Plast Reconstr Surg. 2007;119(6):138-48.

6. Donski PK, Fogdestam I. Distally based fasciocutaneous flap from the sural region. A preliminary report. Scand J Plast Reconstr Surg. 1983;17(3):191-6.

7. Masquelet AC, Romana MC, Wolf G. Skin island flaps supplied by the vascular axis of the sensitive superficial nerves: anatomic study and clinical experience in the leg. Plast Reconstr Surg. 1992;89(6):1115-21.

8. Parrett BM, Pribaz JJ, Matros E, Przylecki W, Sampson CE, Orgill DP. Risk analysis for the reverse sural fasciocutaneous flap in distal leg reconstruction. Plast Reconstr Surg. 2009;123(5):1499-04.

9. Olawoye OA, Ademola SA, Iyun K, Michael A, Oluwatosin O. The reverse sural artery flap for the reconstruction of distal third of the leg and foot. Int Wound J. 2014;11:210-4.

10. Kneser U, Bach AD, Polykandriotis E, Kopp J, Horch RE. Delayed reverse sural flap for staged reconstruction of the foot and lower leg. Plast Reconstr Surg. 2005;116(7):1910-7. 
11. Erdmann D, Gottlieb N, Humphrey JS, Le TC, Bruno W, Levin LS. Sural flap delay procedure: a preliminary report. Ann Plast Surg. 2005;54(5):562-5.

12. Erdmann D, Levin S. Delayed reverse sural flap for staged reconstruction of the foot and lower leg. Plast Reconstr Surg. 2006;118(2):571-2.
Cite this article as: Gupta M, Varshney D, Biswkarma VK. Post road traffic accident one-month old, extra-large heel defect coverage by delayed reverse sural artery flap: an interesting case report. Int Surg J 2021;8:2469-72. 